\title{
Impact of Organized Retail on Unorganized Retail Sector
}

\author{
R. Sivanesan ${ }^{1}$ and G. Jones Green ${ }^{2}$ \\ ${ }^{1}$ Research Scholar, Department of Business Administration, \\ ${ }^{2}$ Research Supervisor, Assistant Professor of Business Administration \\ ${ }^{1 \& 2}$ Scott Christian College (Autonomous), Nagercoil, Kanyakumari, Tamil Nadu, India \\ (Affiliated to Manonmaniam Sundaranar University, Tirunelveli, Tamil Nadu, India) \\ E-Mail: dr.sivanesan25@gmail.com
}

\begin{abstract}
Retail is currently the flourishing sector of the Indian economy. This trend is expected to continue for at least the next two-three decades, and it is attracting huge attention from all entrepreneurs, business heads, investors as well as real estate owners and builders. Availability of quality, retail space, wider availability of products and brand communication are the some important factors that are driving the retail in India. Retail sector is also supporting to create huge employment while a new form of organized retail sector has emerged within the retail industry and it gave speedy phase to Indian retail sector. The rationale of the study is twofold: First, to examine the nature of changes in the retail sector taking place due to organized form of retailing and implications of shift to this new form of retailing. Secondly, this area has remained largely an unexplored part of research till date especially in the Indian context. The broad objective of the study is to understand consumer behavior towards organized and unorganized retail stores and to find out the consumers satisfaction level from organized retail stores as well as unorganized retail stores. The perception of the traditional retailers about the modern retailing. The study uses primary data collected through in depth qualitative analysis to represent organized and unorganized retail sectors respectively. The present study focuses on Kanyakumari, Tirunelveli, Tuticorin, Madurai and Viruthunagar Districts of Tamil Nadu.

Keywords: Retailing, Impact, Organized Retailing, Unorganized Retail
\end{abstract}

\section{INTRODUCTION}

Retailing is one of the largest industries in India the biggest sources of employment in the country. It is the most active and attractive sector and it is going through a transition phase not only in India but also worldwide. The Retailing is a distribution channel function, where one organization buys products from supplying firms or manufactures products themselves, and then sells these directly to consumers. The Indian retail industry has been seen as a potential goldmine for investors from all over the world and a latest research has rated India as the top destination for retailers for an attractive emerging retail market.

India's vast middle class and its most an untapped retail industries are key attractions for global retail giants wanting to enter newer markets. Even though India has well over 5 million retail outlets, the country sorely lacks anything that can resemble a retailing industry in the modern sense. Parallel to the growth of economy and consumerism, development of retail in India may witness the same phases as witnessed by developed countries. So, Retailers in India can learn a few things from their global counterparts. But at the same time, with no legacy of assets to carry forward, there is ample opportunity to leapfrog for retailers in India.

\section{SIGNIFICANCE OF RETAIL INDUSTRY}

In today's competitive business environment, retailers have redefined their role in general, and in the value chain in particular. Retailers are acting as gatekeepers who decide on which new products should find their way to the shelves of their stores. As a result, they have a strong say in the success of the product or services launched by a business firm.

A product manager of household appliances claimed, "Marketers have to sell the new products several times, first within the company, then to the retailer and finally to the user of the product". It is known truth that now a day's Manufactures are forced to identify and find the suitable retail format in order to sell their manufactured products, and also such retail formats needed to be matched according to their business strategy, which in turn helps in building and maintaining their core competencies.

The role of retailers in the present competitive environment has gained attention from manufacturers by external parties such as market intermediaries and supplying partners are becoming increasingly powerful. It is necessary for marketers of consumer products to identify the needs and motivations of their partners in the marketing channel. This is especially true in the case of new products.

Consumer companies might improve their new product success rate if they put more effort in creating retail value as well as consumer differential advantages. If the objectives of a manufacturer, are incompatible with those of the market intermediary such is the retailer, the success of a product is jeopardized. 
TABLE I RECENT M\&A DEALS IN THE INDIAN RETAIL SECTOR

\begin{tabular}{|l|c|c|c|}
\hline \multicolumn{1}{|c|}{ Acquirer name } & Target name & Year & Deal type \\
\hline Walmart & Flipkart & May 2018 & Acquisition \\
\hline Future Group & HyperCity & October 2017 & Acquisition \\
\hline Berger Paints & Chugoku Marine Paints & April 2017 & Collaboration \\
\hline Myntra & InLogg & April 2017 & Acquisition \\
\hline Flipkart owned Myntra & HRX & August 2016 & Acquisition \\
\hline Myntra & MotoGP & August 2016 & Collaboration \\
\hline Aditya Birla Fashion and Retail & Forever 21 (India Business) & May 2016 & Acquisition \\
\hline Idein Ventures. & Infurnia & Jan 2016 & Joint Venture \\
\hline Paytm & Near.in & Dec 2015 & Acquisition \\
\hline Morgan Stanley & Flipkart & June 2015 & Private Equity \\
\hline InnoVen Capital & July 2015 & Private Equity \\
\hline Snapdeal & Sportsbiz Private Limited & Feb 2015 & Acquisition \\
\hline KalyanJewellers India Pvt Ltd & Warburg Pincus & Oct 2014 & Private Equity \\
\hline Celio & Future Lifestyle FashionsLimited & Oct 2014 & Private Equity \\
\hline Flipkart & Myntra.com & May 2014 & Acquisition \\
\hline Soft Bank & Snapdeal & Oct 2014 & Private Equity \\
\hline Warburg Pincus & Biba Apparels & Dec 2013 & Private Equity \\
\hline Hassan Food Co & Landmark Ltd & Feb 2013 & Acquisition \\
\hline Trent Ltd & Bush Foods Overseas Pvt Ltd & Apr 2013 & Acquisition \\
\hline & Source: Bloomberg and Thomson ONE Banker \\
\hline
\end{tabular}

\section{REVIEW OF LITERATURE}

The following are the important review related with present study.

According the study of Indian Council for Research in International Economic Relations (ICRIER) developed research report titled "Impact of organized retail on the unorganized sector" states that retail trade alone accounts for 41.83 percent job opportunities with 14.95 million employed in the sector. Establishments involved in retail trade claimed the highest percentage both in the rural (39.28 percent) and urban (45 percent) areas. It has been the most sought after activity amongst own account establishments with a share of 48.45 percent. In rural areas, 46.52 percent own account establishments were set up for retail trade while the percentage was 51.44 in urban areas. Retail trade along with manufacturing and social and personal service activities have emerged as the three major non-agricultural activities giving the maximum number of jobs, with a share of more than 72 percent of the total establishments. Manufacturing establishments followed retail trade with 8.32 million people employed. Social and personal service activities employed 7.35 percent during the review period.

Michael Levy and Barton Weitzin their book titled "Retailing Management" is definitely a different form of commentary on Retailing Operations' especially in the modern and the Western World. The book discusses different facets of retailing strategies as they are useful for developing the retail markets especially in a growing economy. In this book the authors have tried to find out the reasons of growth of modern retailing, different retail format, and multichannel retailing as a method of operating in a competitive market. From the author's point of view there is a great change in the consumer behaviour which is influencing the pattern of retailing and their strategies.

The consumers have changed not only in terms of perception, choices and ideas and identities but also their modes of buying have significantly varied. These changes in the formats of retailing cannot convince the consumers as to why they should buy the particular product from a particular retail outlet. The change in the formats of branding i.e. from manufacturing brand to retail branding or private labeling has also proved to be of a limited impact. Therefore new methods of promotion especially attracting and retaining consumer, changes in the POP display system are being introduced. The buying systems have changed, so do the buying methods and promotional methods also have changed. The retailers have tried to introduce new pricing strategy and the retail communication has become a more important aspect of retail management in the modern world.

Hamilton Ryaninhis research paper "Assortment size and option attractiveness in consumer choice among retailers" majorly focused on the important decision that retailers always involves in selecting the number of items constituting their assortments. A key issue in making these decisions is the role of assortment size in determining consumers' choice of a retailer. The authors address this issue by investigating how consumer choice among retailers offering various-sized assortments is influenced by the attractiveness of the options constituting these assortments. 
The data show that consumer preference for retailers offering larger assortments tends to decrease as the attractiveness of the options in their assortments increases and can even lead to a reversal of preferences in favour of retailers offering smaller assortments. This research further presents evidence that the relationship between assortment size and option attractiveness is concave, such that the marginal impact of assortment size on choice decreases as the attractiveness of the options increases. Data from eight empirical studies offer converging evidence in support of the theoretical predictions.

Bradford Kevin, Stringfellow Anne and Weitz Barton A in their research article titled "Managing conflict to improve the effectiveness of retail networks", have found that the retailers are becoming involved with networks consisting of multiple firms in order to more effectively perform business activities such as supply chain management. This research develops and tests a framework outlining the effects of conflict in networks and how conflict management can mitigate and exacerbate these effects. A study of 81 simulated networks finds that inter-personal and task conflict have a negative effect on network member satisfaction and desire to be a member of the network. The use of a collaborative conflict management style has a positive effect on satisfaction and desire for continuity, but the effects of accommodative and confrontational styles depend on the level of inter-personal and task conflict present in the network.

Kaltcheva Velitchka in her article titled "When Should a Retailer Create an Exciting Store Environment?" found that the conceptual framework which proposes that the consumer's motivational orientation moderates the effect of the arousal produced by a store environment on the pleasantness of the environment. When consumers have a recreational motivational orientation, high arousal has a positive effect on pleasantness, but when consumers have a task-oriented motivational orientation, high arousal decreases pleasantness. In addition, high arousal increases consumer intentions to visit and make purchases in the store for recreationally oriented consumers, but it has a negative impact on shopping behavior for task-oriented consumers. Pleasantness mediates the effect of arousal on shopping behavior.

Kaufman Peter, Jayachandran and Rose Randall, in their article titled "Problems of Retailers", they have found that retailers face considerable risk in introducing new products because of high failure rates. Given the proliferation of new products juxtaposed against finite shelf space, retail buyers are confronted with a choice problem. To enhance understanding of this issue, the authors examine the role of buyer-salesperson and firm-firm relationships using data collected in the context of actual new product selection by retail buyers at two large grocery retailers in the United States.
The findings indicate that buyer-salesperson and firm-firm relationships have a greater influence on new product acceptance when a new product's attractiveness is modest than when the new product is very unattractive or very attractive. At modest levels of product attractiveness, the likelihood of new product acceptance can increase by as much as 60 percent when the buyer has a strong relationship with the salesperson. The paper provides insights into the complex interplay of marketing relationships and product attractiveness in retail buyers' selection of new products.

Raff Horst and Schmitt Nicolasin their article titled "Buyer power in international markets" they found that the implications for international markets of the existence of retailers/wholesalers with market power. Two main results were shown. First, in the presence of buyer power, trade liberalization may lead to retail market concentration. Due to this concentration, retail prices may be higher and welfare may be lower in free trade than in autarky, thus reversing the standard effects of trade liberalization. Second, the pro-competitive effects of trade liberalization are weaker under buyer power than under seller power.

Buchanan, Simmons and Barbara "Brand Equity Dilution: Retailer Display and Context Brand Effects", they highlights that consistency among the various elements of a marketing program believed essential in building and maintaining brand image and equity. And yet, a brand's ultimate presentation to customers is controlled more often by the retailer than by the manufacturer. The retailer's display decision can negate the equity of an established brand. The author suggests that this occurs because consumers have expectations about retail displays and the relationship among displayed brands. Display conditions that disconfirm these expectations can lead consumers to reevaluate the brand.

\section{OBJECTIVES OF THE STUDY}

The following are the important objectives of the study.

1. To find out the impact organized on unorganized retailing.

2. To offer suggestions for the effective implementation of the retailing activities.

\section{HYPOTHESES}

The following are the hypotheses framed by the researchers.

1. Ho: There is no significant difference between the application of new technologies used by organized retailers and the unorganized retailers.

2. Ho: There is no significant difference between the variety of goods offered by organized retailers and the unorganized retailers.

3. Ho: There is no significant difference between staff strength and the type of organized retailers and unorganized retailers. 
4. Ho: There is no significant difference between the business area in square feet and the type of retail stores of organized retailers and the unorganized retailers.

5. Ho: There is no significant difference between the type of retail stores and the level of impact in business of organized and unorganized retailers.

\section{METHODOLOGY}

The purposive sampling procedure has been adopted to identify the sample retailers included in the present study. The total sample size of retailers is 250. Hence the considered retailers for the present study in five city headquarters are from each city with 50 retailers each.

The criteria of the sampling plan undertaken are as follows.

1. Target Population or Universe: Unorganized retail

2. Business selected: Grocery shop, General shop, Petty shop, Fruit vendor, and Vegetable Shop.

3. Sampling Method: Purposive Sampling technique

4. Sample Size: 250
5. Area of Survey: Kanyakumari, Tirunelveli, Tuticorin, Madurai and Viruthunagar

\section{ANALYSIS AND INTERPRETATION}

Retail Industry is continually going through changes on account of liberalization, globalization, and consumer preferences. While multi-national retail chains are looking for new markets, manufacturers are identifying, redefining or evolving new retail formats. In the recent times, Even the emerging and existing retail players has geared themselves in order to face the upcoming strong and major competition in the organized retail sector, wherein these changed the outlook among the consumers perception towards retail players. Now a day's consumers are not only looking for the core products or functional benefits from the retailers, but also they expect the non-functional benefit, which needs to be compatible with their lifestyles. Hence the researchers analyze the impact of organized retail on unorganized retail is as follows.

TABLE II IMPACT OF ORGANIZED RETAIL SECTOR

\begin{tabular}{|c|l|c|c|c|c|}
\hline S. No. & \multicolumn{1}{|c|}{ Factor } & $\begin{array}{c}\text { Will } \\
\text { Affected }\end{array}$ & $\begin{array}{c}\text { Not } \\
\text { Affected }\end{array}$ & Affected & Total \\
\hline 1 & $\begin{array}{l}\text { Impact of organized retail stores and the application } \\
\text { of new technology }\end{array}$ & $50(20)$ & $30(12)$ & $170(68)$ & 250 \\
\hline 2 & Impact of organized retail variety of goods & $60(24)$ & $40(16)$ & $150(60)$ & 250 \\
\hline 3 & Impact of staff strength and the type of retail business & $45(18)$ & $32(13)$ & $173(69)$ & 250 \\
\hline 4 & $\begin{array}{l}\text { Impact of business area in square feet and the type of } \\
\text { retail stores }\end{array}$ & $20(08)$ & $20(08)$ & $210(84)$ & 250 \\
\hline 5 & Types of retail stores and the level of impact in business & $55(22)$ & $48(19)$ & $147(59)$ & 250 \\
\hline
\end{tabular}

The modern day business is more governed and driven by the technology and which has a positive and negative implication on the business and hence the question relating to the impact of technology on the type of retail stores are gathered and the results are presented in the above table. From the above Table II shows that, 20 percent (50 respondents) feels that, unorganized retail stores will affected in future due to the entry of organized retail outlets and their application of new technology, 12 percent (30 respondents) feels that, unorganized sectors don't affected due to the new technology adopted by organized stores, and 68 percent (170 respondents) feels that, unorganized retail stores and the application of new technologies are affected due to the entry of organized retail outlets.

Varieties of goods are playing important role for analyzing the impact of organized retail outlets on unorganized retail outlets. Now-a-days consumers are giving important to the types and varieties of goods handled by the retailers. From the above table shows that, 150 respondents (60 percent) feels that, unorganized retail stores affected due to varies types of goods handled by organized retail outlets, 60 respondents ( 24 percent) feels that, unorganized retail stores will affected in future due to varies types of goods handled by organized retail outlets, and 40 respondents (16 percent) feels that, unorganized retail stores not affected due to varies types of goods handled by organized retail outlets.

Staff strength and types of retail business are playing very important role to analyze the impact of organized retail outlets on unorganized retail outlets. The above table shows that, 45 unorganized retailers (18 percent) feel that unorganized retail outlets will affected by the staff strength and types of organized retail outlets, 32 unorganized retailers (13 percent) feels staff strength and types of retail business is not affected and 173 respondents (69 percent) feel that unorganized retail outlets are affected by the strength and types of organized retail business.

Space and types of business are playing important role to analyze the impact of organized retail outlets on unorganized retail outlets. The above table shows that, 20 unorganized retailers ( 8 percent) feels that unorganized retail outlets will affected by space and types of organized retail outlets, 20 unorganized retailers (08 percent) feels space and types of organized retail outlets is not affected and 210 respondents (84 percent) feel that unorganized retail outlets are affected by the space and types of organized retail outlets. 
Types of retail stores are playing important role to analyze the impact of organized retail outlets on unorganized retail outlets. The above table shows that, 55 unorganized retailers (22 percent) feels that unorganized retail outlets will affected by the types of organized retail outlets, 48 unorganized retailers (19 percent) feels types of retail stores of organized retail outlets is not affected and 147 respondents (59 percent) feel that unorganized retail outlets are affected by the types of retail stores of organized retail outlets.

TABLE III THE STATEMENTS Of UnORganized Retail On Likert SCALE

\begin{tabular}{|c|c|c|c|c|c|c|c|c|c|}
\hline \multirow{2}{*}{$\frac{\text { S. No. }}{1}$} & \multirow{2}{*}{$\begin{array}{l}\text { Statements of response from unorganized retailer } \\
\text { The growing organized retail is threat to your business? }\end{array}$} & \multicolumn{7}{|c|}{$\begin{array}{c}\text { (Please rank1-7, } 1 \text { for strongly Agree and } 7 \text { strongly } \\
\text { disagree) }\end{array}$} & \multirow[b]{2}{*}{1432} \\
\hline & & $\begin{array}{c}98 \\
(686)\end{array}$ & $\begin{array}{c}57 \\
(342) \\
\end{array}$ & $\begin{array}{c}45 \\
(225) \\
\end{array}$ & $\begin{array}{c}32 \\
(128) \\
\end{array}$ & $\begin{array}{c}15 \\
(45) \\
\end{array}$ & $\begin{array}{c}03 \\
(06)\end{array}$ & $\begin{array}{c}00 \\
(00) \\
\end{array}$ & \\
\hline 2 & $\begin{array}{l}\text { Profit is negatively effecting as organized retailers are } \\
\text { increasing in number. }\end{array}$ & $\begin{array}{c}105 \\
(735)\end{array}$ & $\begin{array}{c}58 \\
(348) \\
\end{array}$ & $\begin{array}{c}40 \\
(200)\end{array}$ & $\begin{array}{c}28 \\
(112)\end{array}$ & $\begin{array}{c}12 \\
(36)\end{array}$ & $\begin{array}{c}05 \\
(10)\end{array}$ & $\begin{array}{c}02 \\
(02) \\
\end{array}$ & 1443 \\
\hline 3 & $\begin{array}{l}\text { Organized retailers monopolize the retail market through } \\
\text { unfair competition }\end{array}$ & $\begin{array}{c}24 \\
(168) \\
\end{array}$ & $\begin{array}{c}54 \\
(324) \\
\end{array}$ & $\begin{array}{c}84 \\
(420) \\
\end{array}$ & $\begin{array}{c}45 \\
(180) \\
\end{array}$ & $\begin{array}{c}28 \\
(84)\end{array}$ & $\begin{array}{c}10 \\
(20)\end{array}$ & $\begin{array}{c}05 \\
(05) \\
\end{array}$ & 1201 \\
\hline 4 & $\begin{array}{l}\text { Sales turnover is reduced as customers are gradually } \\
\text { shifting towards organized retail store. }\end{array}$ & $\begin{array}{c}110 \\
(770)\end{array}$ & $\begin{array}{c}55 \\
(330) \\
\end{array}$ & $\begin{array}{c}45 \\
(225) \\
\end{array}$ & $\begin{array}{c}25 \\
(100) \\
\end{array}$ & $\begin{array}{c}10 \\
(30)\end{array}$ & $\begin{array}{c}05 \\
(10)\end{array}$ & $\begin{array}{c}00 \\
(00) \\
\end{array}$ & 1465 \\
\hline 5 & $\begin{array}{l}\text { Prices of the goods are more competitive due to large } \\
\text { volumes by organized retailers. }\end{array}$ & $\begin{array}{c}96 \\
(672) \\
\end{array}$ & $\begin{array}{c}59 \\
(354) \\
\end{array}$ & $\begin{array}{c}42 \\
(210)\end{array}$ & $\begin{array}{c}27 \\
(108)\end{array}$ & $\begin{array}{c}19 \\
(57)\end{array}$ & $\begin{array}{c}04 \\
(08)\end{array}$ & $\begin{array}{c}03 \\
(03) \\
\end{array}$ & 1412 \\
\hline 6 & $\begin{array}{l}\text { Organized retailers give more discounts and offers as they } \\
\text { are operating on larger volume of consumer purchase. }\end{array}$ & $\begin{array}{c}99 \\
(693)\end{array}$ & $\begin{array}{c}65 \\
(390) \\
\end{array}$ & $\begin{array}{c}45 \\
(225) \\
\end{array}$ & $\begin{array}{c}25 \\
(100)\end{array}$ & $\begin{array}{c}10 \\
(30)\end{array}$ & $\begin{array}{c}05 \\
(10)\end{array}$ & $\begin{array}{c}01 \\
(01)\end{array}$ & 1449 \\
\hline 7 & $\begin{array}{l}\text { Service and quality expectations of customer are increased } \\
\text { due to growing organized retail. }\end{array}$ & $\begin{array}{c}118 \\
(826)\end{array}$ & $\begin{array}{c}58 \\
(348) \\
\end{array}$ & $\begin{array}{c}30 \\
(150)\end{array}$ & $\begin{array}{c}25 \\
(100)\end{array}$ & $\begin{array}{c}12 \\
(36)\end{array}$ & $\begin{array}{c}05 \\
(10)\end{array}$ & $\begin{array}{c}02 \\
(02) \\
\end{array}$ & 1472 \\
\hline 8 & $\begin{array}{l}\text { Customer demand more variety now with the growth of } \\
\text { organized retail. }\end{array}$ & $\begin{array}{c}92 \\
(644)\end{array}$ & $\begin{array}{c}56 \\
(336) \\
\end{array}$ & $\begin{array}{c}42 \\
(210) \\
\end{array}$ & $\begin{array}{c}25 \\
(100)\end{array}$ & $\begin{array}{c}19 \\
(57)\end{array}$ & $\begin{array}{c}11 \\
(22)\end{array}$ & $\begin{array}{c}05 \\
(05) \\
\end{array}$ & 1374 \\
\hline 9 & Customer now wants their products to be delivered at home. & $\begin{array}{c}27 \\
(189)\end{array}$ & $\begin{array}{c}32 \\
(192) \\
\end{array}$ & $\begin{array}{c}48 \\
(240) \\
\end{array}$ & $\begin{array}{c}58 \\
(232) \\
\end{array}$ & $\begin{array}{c}68 \\
(24) \\
\end{array}$ & $\begin{array}{c}12 \\
(24)\end{array}$ & $\begin{array}{c}05 \\
(05) \\
\end{array}$ & 1086 \\
\hline 10 & $\begin{array}{l}\text { Customer demand of branded merchandise is increasing } \\
\text { due to growth in Organized retail. }\end{array}$ & $\begin{array}{c}108 \\
(756) \\
\end{array}$ & $\begin{array}{c}58 \\
(348) \\
\end{array}$ & $\begin{array}{c}40 \\
(200)\end{array}$ & $\begin{array}{c}25 \\
(100)\end{array}$ & $\begin{array}{c}12 \\
(36)\end{array}$ & $\begin{array}{c}05 \\
(10)\end{array}$ & $\begin{array}{c}02 \\
(02) \\
\end{array}$ & 1452 \\
\hline 11 & $\begin{array}{l}\text { Some of the small retail businesses around me are shut } \\
\text { down due to growing organized retail stores. }\end{array}$ & $\begin{array}{c}67 \\
(469) \\
\end{array}$ & $\begin{array}{c}75 \\
(450) \\
\end{array}$ & $\begin{array}{c}54 \\
(270) \\
\end{array}$ & $\begin{array}{c}35 \\
(140)\end{array}$ & $\begin{array}{c}12 \\
(36) \\
\end{array}$ & $\begin{array}{c}05 \\
(10)\end{array}$ & $\begin{array}{c}02 \\
(02) \\
\end{array}$ & 1377 \\
\hline 12 & $\begin{array}{l}\text { Some other small retailers are struggling and running on } \\
\text { losses due because of growing organized retail stores. }\end{array}$ & $\begin{array}{c}121 \\
(847)\end{array}$ & $\begin{array}{c}58 \\
(348) \\
\end{array}$ & $\begin{array}{c}37 \\
(185) \\
\end{array}$ & $\begin{array}{c}15 \\
(60) \\
\end{array}$ & $\begin{array}{c}12 \\
(36) \\
\end{array}$ & $\begin{array}{c}05 \\
(10) \\
\end{array}$ & $\begin{array}{c}02 \\
(02) \\
\end{array}$ & 1488 \\
\hline 13 & $\begin{array}{l}\text { Retail business becomes difficult as it requires more capital } \\
\text { due to increasing number organized retailers in the market. }\end{array}$ & $\begin{array}{c}72 \\
(504)\end{array}$ & $\begin{array}{c}75 \\
(450) \\
\end{array}$ & $\begin{array}{c}50 \\
(250) \\
\end{array}$ & $\begin{array}{c}31 \\
(124)\end{array}$ & $\begin{array}{c}12 \\
(36)\end{array}$ & $\begin{array}{c}05 \\
(10)\end{array}$ & $\begin{array}{c}02 \\
(02)\end{array}$ & 1376 \\
\hline
\end{tabular}

In the above Table III shows that, unorganized retailers heavily affected due to various factor after the entry of organized retail outlets. The growth of organized retail outlets are affected the unorganized retail outlets.

TABLE IV ANALYSIS OF HYPOTHESIS

\begin{tabular}{|c|c|c|c|c|c|c|}
\hline $\begin{array}{c}\text { S. } \\
\text { No. }\end{array}$ & Hypothesis $\left(\mathrm{H}_{0}\right)$ & $\begin{array}{l}\text { Table } \\
\text { Value }\end{array}$ & $\begin{array}{l}\text { Calculated } \\
\text { Value }\end{array}$ & $\begin{array}{c}\text { Degrees of } \\
\text { freedom }\end{array}$ & $\begin{array}{c}\text { Level of } \\
\text { Significance }\end{array}$ & Result \\
\hline 1 & $\begin{array}{l}\text { There is no significant association between the new } \\
\text { technologies used by organized retailers and the } \\
\text { unorganized retailers }\end{array}$ & 09.49 & 19.58 & 4 & 0.050 & Rejected \\
\hline 2 & $\begin{array}{l}\text { There is no significant association between the impact } \\
\text { of variety of goods by organized retailers and the } \\
\text { unorganized retailers }\end{array}$ & 09.49 & 28.69 & 4 & 0.050 & Rejected \\
\hline 3 & $\begin{array}{l}\text { There is no significant association between staff } \\
\text { strength and the type of organized retailers and } \\
\text { unorganized retailers }\end{array}$ & 09.49 & 48.21 & 4 & 0.050 & Rejected \\
\hline 4 & $\begin{array}{l}\text { There is no significant association between the } \\
\text { business area in square feet and the type of retail stores } \\
\text { of organized retailers and the unorganized retailers }\end{array}$ & 09.49 & 71.58 & 4 & 0.050 & Rejected \\
\hline 5 & $\begin{array}{l}\text { There is no significant association between the type of } \\
\text { retail stores and the level of impact in business of } \\
\text { organized and unorganized retailers. }\end{array}$ & 09.49 & 16.22 & 4 & 0.050 & Rejected \\
\hline
\end{tabular}

1. The calculated value of chi-square $\left(\chi^{2}\right)$ value is 19.58 , degrees of freedom 4 and the level of significance is .050 , which is greater than the table value. Hence the null hypothesis is rejected. Therefore, there is significant association between the new technologies used by organized retailers and the unorganized retailers. 
2. The calculated value of chi-square $\left(\chi^{2}\right)$ value is 28.69 , degrees of freedom 4 and the level of significance is .050 , which is greater than the table value. Hence the null hypothesis is rejected. Therefore, there is significant association between the impact of variety of goods by organized retailers and the unorganized retailers.

3. The calculated value of chi-square $\left(\chi^{2}\right)$ value is 48.21 , degrees of freedom 4 and the level of significance is .050 , which is greater than the table value. Hence the null hypothesis is rejected. Therefore, there is significant association between the staff strength and the types of organized retailers and unorganized retailers.

4. The calculated value of chi-square $\left(\chi^{2}\right)$ value is 71.58 , degrees of freedom 4 and the level of significance is .050 , which is greater than the table value. Hence the null hypothesis is rejected. Therefore, there is significant association between the business area in square feet and the type of retail stores of organized retailers and the unorganized retailers.

5. The calculated value of chi-square $\left(\chi^{2}\right)$ value is 16.22 , degrees of freedom 4 and the level of significance is .050 , which is greater than the table value. Hence the null hypothesis is rejected. Therefore, there is significant association between the type of retail stores and the level of impact in business of organized and unorganized retailers.

\section{FINDINGS OF THE STUDY}

Unorganized retailer's mainly small neighborhood stores are found to have negative impact of growing organized retail stores. Customers have started moving to more modern organized retail stores. As a result unorganized retailers are preparing for a competitive response through improved marketing and technological practices in the market. The broader understanding from the research showed that there is sufficient space in the market for both the form of retail sustainability and growth.

1. This study clearly shows that unorganized retailers located near organized retailers have been adversely affected in terms of their volume of business and profit.

2. The unorganized retailers believe that the unfair competition from organized retailers lead to competitive prices in retail business and thus reduces their margins.

3. It is also found in the research that organized retailers also provide more discounts and offers due to economies of scale which is a reason of worry for unorganized retailers.

4. Organized retailers has increased the service quality expectations of the customers, to meet the enhanced expectations of the customers small retailers have to make more investment into the business and also increase their operational cost.

5. Organized retailers provide more variety and branded merchandise to consumers which is again a reason of concern for small retailers in unorganized retail sectors.
6. Organized retailers also provide home delivery of their goods to customers which is difficult for unorganized retailers with small investment.

7. The study results that retail business is becoming more difficult for small entrepreneurs because it requires more capital to start the shop, current operational expenses is increased as customer preferences is changing with the advent of organized retail stores.

8. There is some small shops are shut down by the direct negative impact of organized retail stores concluded in the study.

9. Unorganized retail has maintained employment levels because of competitive response by be modernizing their store, started using technology and improved services for the customer but the threat is strongly perceived about their employment.

10. Unorganized retailers have significant competitive strengths that include consumer goodwill, credit sales, and amenability to bargaining, ability to sell loose items, convenient timings also indicated in the study.

\section{SUGGESTIONS OF THE STUDY}

The following are the important suggestions of the present study.

1. The unorganized retail stores must develop the ambience and annex more types of goods into their retail outlets and must try to function on par with the organized retail stores as it is an easy methodology in the globalised scenario of business.

2. The study area comprises of more number of villages which is a potential market to the unorganized retail business and in no way this market can be tapped by the organized system of retail business.

3. In all the areas of study, there is a partial or a meager level of impact on the emergence of organized retail stores and they intend to build their business across the country. It should be a wakeup call to the organized retailers to establish and sustain in their business.

4. Innovations and creativity should be a new mantra of business. Hence, the organized retail business must come forward to introduce more innovations and creative business techniques to withstand and survive well in the business.

5. Government should facilitate the understanding of government polices among the unorganized retailers and should educate and create awareness among the unorganized retailers to reframe and modify business according to the needs of changing times.

6. Unorganized retailers should focus on affinity towards the local culture, custom, tradition and customers. It is very important in globalized era of market to handle the changing myopia.

7. As far as the unorganized retail sector is concerned they should make a careful study before making investments in the expansion and development programme of their business as it is of a biggest challenge is the retail space in the competitive situation of business establishment and organizations. 
8. India has a maximum population residing in rural area and it is also observed that the consumers are price sensitive; in India there exist multi dimension cultured people. Therefore a critical analysis needs to be done of all these environmental needs on a continuous basis by the modern unorganized retailers before zeroing in on any particular format of organized retail in any part of the Indian market

\section{CONCLUSION}

Retail sector is playing very important role in the development of a country. It is clear from the study, that the unorganized retailers clearly understood the impact of the organized retailers on their business in terms of sales, profit and employment. But they are struggling to introduce changes in their existing retail practices due to their financial illness, traditional accepted formats, no creativity / innovations and the like. In view of customers, the unorganized retailers have least advantage over the emerging organized retailers. Some kind of intervention is required for their future existence as everything changes with changing times and fashion. So initiatives should be taken to protect the interest of the unorganized sector as this sector has the employment potential, wide coverage of market, service to local and required population and opportunity for entrepreneurship development in the country as the most of the retail outlets have less than one lakh rupee of investments and are belonging to the low income families that serves the society with social responsibility beyond profit making.

\section{SCOPE OF THE FURTHER RESEARCH}

This research will provide greater understanding of the impact of organized retailer on unorganized retailer, further research is encouraged to various other segments of the industry like apparel, electronics etc. This research is based on the grocery shop, general shop, petty shop, fruit vendor, and vegetable Shop of five district of Tamil Nadu, further the study can be done on other cities and geographic locations of the country. Impact of organized retail on supply chain can be deeply analyzed in further research. The other major evolution in retail industry in present scenario is online retailing, so further research has to be done as to how the change is going to affect overall retail market. Then there is different segments in online retailing which can be studied and how these changes in marketplace is effecting different stakeholders of the industry particularly the customer.

\section{REFERENCES}

[1] Barry Berman \& Joel Evans R. (2007). Retail Management a Strategic Approach, $\left(10^{\text {th }}\right.$ edition) Dorling Kindersley Publication.

[2] Chetan Bajaj, Rajnish Tuli \& Nidhiv Srivastava. (2008). Retail Management, (11th Impression), Oxford University Press, New Delhi.

[3] Levy Michael \& Weitz Barton. (2008). Retailing Management, McGraw Hill. Pearson Education Inc., Dorling Kindersley Publication.

[4] Banerjee, Arindam \& Bibek Banerjee. (2004). Effective Sales Promotion Management: Use of Point of Sales Information, 25(4), 51-59.

[5] Bradford Kevin D., Stringfellow Anne \& Weitz Barton A. (2004). Managing conflict to improve the effectiveness of retail networks, Journal of Retailing, (80), 181-195.

[6] Buchanan Lauranne, Simmons Carolyn J., \& Bickart Barbara A. (1999). Brand Equity Dilution: Retailer Display and Context Brand Effects, Journal of Marketing Research, 36, 345-355.

[7] Backstrom, K. and Johansson, U. (2006), Creating and Consuming Experiences in Retail Store Environments: Comparing Retailer and Consumer Perspectives, Journal of Retailing and Consumer Services, 13(6), 417-430.

[8] Boedekar, M. (1995). New-type and Traditional Shoppers: A Comparison of Two Major Consumer Groups, International Journal of Retail and Distribution Management, 23(3), 17-26.

[9] Deepti Chaudhary, (2008). As organized retailing takes off in India, so do discount chains, Live Mint and The Wall Street Journal, 04, 1822.

[10] Dixit, K. (2008). Retail Marketing in India; Key Issues and Challenges, Marketing Mastermind, 2, 13-23, www.iupindia.in.

[11] Hamilton Ryan. (2009). Assortment size and option attractiveness in consumer choice among retailers, Journal of Marketing Research, 46, 410-420.

[12] Kaltcheva Velitchka D. (2006). When should a Retailer Create an Exciting Store Environment?, Journal of Marketing, 70, 107-118.

[13] Kaufman Peter, Jayachandran Satish, \& Rose Randall L. (2006). Problems of retailers, Journal of Marketing Research, 43, 580-587.

[14] Kumar, N. (1997). The Revolution in Retailing: From Market Driven to market Driving, Long Range Planning, 30(6), 830- 835.

[15] Mukherjee, A. \& Patel, N. (2005). Retailing in India: Recent Trends and development Survey Findings, Journal of Marketing and Communication, 1(2), 4-42.

[16] Mulky, A. \& Nargungkar, R. (2003). Modernization in Indian Retailing: Managerial and Policy Perspectives, UdyogPragati, 27(2), $1-8$.

[17] Reimers, V. \& Clulow, V. (2009). Retail Centres: It's Time to Make Them Convenient, International Journal of Retail and Distribution Management, 37(7), 541 -562.

[18] Reynolds, J., Howard, E., Cuthbertson, C. \& Hristov, L. (2007). Perspectives on Retail Format Innovation: Relating Theory and Practice, International Journal of Retail and Distribution Management, 35(8), 647-660.

[19] Raff Horst \& Nicolas Schmitt Nicolas, (2009). Buyer power in international markets, Journal of International Economics, 79, 222230.

[20] Stoel, L., Wickliffe, V. \& Lee, K. H. (2004). Attributes Belief and spending as Antecedents to Shopping Value, Journal of Business Research, 57(10), 1067-1073. 